\title{
Design and social sustainability: new perspectives for the contemporary city based on participation
}

\author{
Pedro Arturo Martínez Osorio ${ }^{1, a}$, Paula da Cruz Landim² and Tomás Queiroz Ferreira Barata ${ }^{3}$ \\ ${ }^{1}$ Unesp, PPGDesign, Av. Eng. Luiz E. C. Coube, 14-01, Bauru, SP, Brasil / Cecar, FCBIA Arquitectura, Colombia. \\ ${ }^{2}$ Unesp, PPGDesign, FAAC, Av. Eng. Luiz E. C. Coube, 14-01, Bauru, SP, Brasil. \\ ${ }^{3}$ Unesp, PGDesign,FAAC, Av. Eng. Luiz E. C. Coube, 14-01, Bauru, SP, Brasil.
}

\begin{abstract}
The objective of this article is to present some of the possibilities that open in the field of Design from a disciplinary reflection based on concepts still under construction such as social sustainability, social innovation and the practice of social design. Some small-scale collaborative interventions are shown in the contemporary city, in which Design appears as a discipline of social mediation and the designer as a facilitator in search of the solution to urgent problems that improve the quality of life of the communities.
\end{abstract}

Keywords. Social Design, social sustainability, social innovation, local development, contemporary city.

\section{Introduction}

The world of today is undoubtedly a context in crisis and constant change (MOURA, 2014), which responds incessantly to the tensions that represent contemporaneity (SALONIA, 2016, p. 669). It speaks increasingly of imbalances and failures in paradigms and models of development; including one of the most urgent is the progressive oblivion towards overcoming poverty and unemployment as central objectives of public policy (IBARRA, 2014, p. 4).

The idea of an interdependent and connected global village has gradually been distorted. The importance of the diversity and specificity of communities is increasingly emphasized, to the point of understanding various categories of globalization, a neutral, a positive and a negative one (MATEI, 2014, p. 542).

Some of the consequences of the rapid growth of global economic globalization have been the alteration of business paradigms and government policies, which have generated unprecedented effects on society, culture and the environment (ABDEL - HADI, 2012, p.11).

At this moment of change and destabilization, new expressions appear as alternatives that seek, among other aspects, decentralization, understood as empowering the local; and participation as an instrument for local development from small-scale initiatives (GIRAUT, 2011, p. $49-50)$.

The concept of sustainability has also evolved from the triad society, environment and economy; to understand more and more the importance of its application in all aspects of social development, on the one hand it appears as an indispensable criterion to be included in the "marketing", beyond being a requirement or an option, now understood as an competitive advantage towards innovation (KUMAR et al., 2012, p. $484)$; on the other hand giving importance to social sustainability (MCKENZIE, 2004) as a concept associated with aspects such as participation, social capital, equity, environment; more recently related with the notions of happiness, well-being and quality of life (EL-HUSSEINY \& KESSEIBA, 2012, p. 792).

Recent reflections on the concept of innovation have also generated interesting contributions in the contemporary panorama, one of them the construction of the so-called "social innovation", concept related to those novel ideas that are developed to meet social objectives (MULGAN et al., 2007, p. 9), which generate alternative solutions to solve urgent problems of the communities.

Disciplines like Design, architecture and urbanism from an inter-disciplinary work have not been outside these changes proposed by the contemporary world. It is increasingly frequent both at a theoretical level and in professional practice, to find a sensible reflection on the contemporary issues that gradually becomes evident in the city; specifically in the public space due to its importance for the development of social relations, since this becomes a scenario of conflict and tensions, product of the relationship of man with his time, in the words of Manuel Castells public space is constituted in "The concrete expression of each historical set in which a society is specified" (CASTELLS, 2012, p. 141).

The aim of this article is to present some of the possibilities that open in the field of Design applied to the realities of the contemporary city. It shows some collaborative interventions in which Design appears as a

\footnotetext{
a Corresponding author: pedro.martinez@cecar.edu.co
} 
discipline of social mediation, and the designer as a facilitator in search of the solution to urgent problems that improve the quality of life of the communities.

\section{Examples}

\subsection{Perspectives for local development in the contemporary city: Design, social sustainability, social innovation and participation.}

As one of the changes in the processes of accommodation of the contemporary world, from the crisis of globalization, there is a growing interest in the idea of sustainable local development; in some developing countries, it became the target of national social and economic development strategies (BERCU, 2015, p. 144).

In these local development strategies, the concept of social sustainability, understood as creating a harmonious living environment, reducing inequality, social division, and improving the quality of life is very important (EL-HUSSEINY \& KESSEIBA, 2012, p. 792). Social sustainability (MCKENZIE, 2004) Is related to various physical factors in the city, especially with the existence, availability and quality of public space (HARUM et al., 2014, p. 606), which after its degradation due to different environmental, social and economic problems, is recently thought of as an important resource that encourages the sustainability of communities.

The public space in the contemporary city, as social construction is something very complex; a place that is constituted in the environment and human habitat for excellence due to the progressive growth of urban life ending the second decade of the 21 st century. On the one hand it is intervened from multiple interests, fulfill of different products of Design, objects, images, symbols, which in some cases make the city a place without harmony, and other times allow it to differentiate and consolidate identity, which can favor a more pleasant and meaningful place for socialization (BULDUK, 2012, p. 3279).

Beyond intervening the public space of the city through Design as a discipline for the development of products that meet the various human needs, in recent years, a theory and practice of Design has been consolidated as a social process based on its potential as part of participatory strategies for social re-assembly, which fit with initiatives that can be called within social innovation, as they seek to find alternative answers to contemporary problems. It is proposed here to change the conventional objective of Design as a generator of objects and products, for a perspective where the result and social benefit of Design is the creation of a network of actors (EKOMADYO \& YULIAR, 2015, p. 159), this new perspective of Design has taken references and bases in theories and strategies for the practice and teaching of Design as "Design thinking" (LAWSON, 1980), "Actor-network theory" (LATOUR, 2005), "participatory Design" (SANDERS Y STAPPERS,
2008), And more recently "Learning Design" (PATARAKING \& SHILOVA, 2015).

In the contemporary city these new perspectives of Design practice with a commitment in the social responsibility of the discipline, are generating very interesting results, since they manage to arrive with concrete results to places where the development plans and the administrations do not reach to give solutions . They are now a new way of understanding citizenship in the 21 st century:

The formation of a new socio-cultural environment has started in 21 st century. The most outstanding feature of it is the productive participation of citizens in collaborative production of knowledge and decision making. In every field of human activity the transition from knowledge consuming and reproduction to immediate participation of people in knowledge production and decision making occurs. (PATARAKING \& SHILOVA, 2015, p. 1083).

This new way of understanding citizenship, in which the Design is integrated from inter and transdisciplinary participatory strategies that summon art, architecture and urbanism among other disciplines, can find as a recent example the contributions in the perspectives of cities development in the so-called "tactical urbanism" (LYDON et al., 2012), which consists of a strategy of small-scale interventions to improve the habitability of the city, starting at the neighborhood, street, block, building or house level.

"Tactical urbanism" is an approximation to the understanding of the practice of a new citizenship with five characteristics: a) a progressive approach to instigated change; B) the provision of local solutions for local planning challenges; C) short-term commitment and realistic expectations; D) low risk, with possibility to high reward; (E) the development of social capital among citizens and the promotion of organizational capacity between institutions and participants (LYDON et al., 2012, p. 1-2).

Numerous tactical urbanism interventions have been developed around the world: Cairo, São Paulo, Tehran, Hangzhou, Paris, Mexico City, Bogota, Lima, New York, etc. It can be said preliminarily that these have in common among others the following design strategies: "defamiliarization" (access to new spaces of the city), "refamiliarization" (re occupation of city spaces vetted), "decommodification" (emphasis on the value of use on the value of change in urban spaces) and the development of "alternative economies" driven by the inhabitants (ELRAHMAN, 2016, p. 226).

Some of the most interesting practices in which Design appears involved in the participatory strategies promoted from tactical urbanism are: the "Pop-up retail", which consists of an intervention that promotes the temporary use of spaces for commercial use; in this initiative is interesting the innovation in the development of prototypes of commercial stand for temporary use in the public space.

Also the initiative of the "Parklets" that tries to reclaim spaces sub utilized in the city, without generating great costs; this strategy highlights the 
creativity in the design of furniture objects for the public space with a low cost, that are attractive and promote the use of public space.

Another strategy is the so-called "Chair bombing", which consists of the increase of urban furniture for the socialization in the public space, from the design and production of objects of urban furniture based on recycled materials. This initiative requires a great creative effort from the planning of the project to the implementation in the public space to achieve the dynamization of spaces previously used by the community.

"Road repair" is another of the low-cost interventions that are promoted from tactical urbanism. This is explored possibilities from the graphic Design applied to the revitalization of pavements of the city, in this, it is innovative the use of color and symbology in the quest to achieve a safer city for pedestrians and cyclists.

There are many examples in the contemporary city that can be cited, in which Design appears as a key discipline for solving problems that affect local development. There is a promising scenario for innovation in Design focused on its transformative potential of reality in search of achieving a sustainable habitat and a higher quality of life for society. One of the most important aspects in this understanding of the social function of Design is its ability to articulate and bring together knowledge that generates empowerment that dynamizes new ways of living and being in the world.

\section{Discussions}

Based on the scenario proposed for the development of an alternative Design practice in the contemporary city, it is interesting to start a discussion about the relevance of this practice of Design as a social process in the contemporary city.

The relevance of the contribution of the Design in the transformation of reality in the contemporary city, going beyond generating products, now also engaged in the creation and empowerment of a network of actors that can streamline their contexts, is pointed out by Bonsiepe in an interview as a necessity for new designers. Bonsiepe (2015a, 78), calls it a new way of interpreting and occupying the concept of citizenship, approaching a political action of Design.

As early as 1978, Bonsiepe had referred to the other role that Design should play, especially in what he calls "peripheral countries". For Bonsiepe in these countries, the Design has an essential political function and meaning, since it focuses on the liberation and not on the perpetuation of the power interests of the hegemonies (BONSIEPE, 1978, p.60).

Also Bonsiepe in 2011, in the same sense speaks of the need to form a critical conscience in the practice of Design; Speaks of the exercise of democracy making possible the "participation of the dominated, to create a space of self-determination"; the development of "design humanism" in the Design (BONSIEPE, 2011, p.20 - 21).
Design professions are faced with the challenge of reversing new professional standards for environmentally compatible design. At the same time, designers began to increasingly address the problems of generation and disposal of waste, use of renewable energy and the use of recyclable materials, that is, they began effectively and concerned with the energy profiles of the products and their relationship with urban space. (BONSIEPE, 2015b, p.135)

Victor Papanek, also gives account of the social and moral responsibilities of the interventions from the Design in the society; refers to Design as a social art for excellence (PAPANEK, 2007, p. 195). He talks about the unnecessary category of "Sustainable Design", stating that it would be easier to reformulate the values and work of Design, so that it was based first on humility and the good of society (p. 14 - 57).

Peter Danko, indicates that we are about to attend a quantum leap in design, of a magnitude never seen since the appearance of the movement of the Bauhaus in the twenties. The cause is the birth of a style. He calls it "ecommodernity" that links sustainability with industrial production (BROWER; MALLORY \& OHLMAN, 2007 p. 16).

Another interesting aspect to reflect upon from identifying the practice of Design as a mediator in the social re-assembly would be about the forms and processes necessary for the same practice. Rafael Cardoso in relation to this discussion argues that in a complex world as the contemporary, the best solutions come from teamwork (CARDOSO, 2012, p. 23), to emphasize as a necessity for the contemporary designer, what Papanek had already raised years before, the capacity and talent of the designer for teamwork and its adaptation to people of many different cultures and areas (PAPANEK, 2007, p. 10).

The design media crisis (BONSIEPE, 2011, p. 18) has gradually given way to increasing concern for sustainability, the development of collaborative works, the creation of local value, co-creation, co-design, participatory design, which for some will become the future of the profession, "Design as activism" (MANZINI, 2014, p. 98).

Sustainability is understood in this vision, from a Design practice not only as a producer of environmentally friendly objects, but from its potential as a facilitator (SANDERS \& STAPPERS, 2008), in order to deal systemically with the problems of contemporaneity, to stimulate and strengthen their capacities (MANZINI \& RIZZO, 2011), in the construction of a new concept, "Social design" (CHEN et al., 2016).

The meeting between design and the environmental theme is tied to the first two levels of interference. Both were and continue to be very useful for ecological issues, but to achieve environmental sustainability, it is no longer enough to improve the existing one, but rather to think about new and previously unknown products and services. Thus, Manzini \& Vezzoli, explain that:

Proposing the development of design for sustainability means, therefore, to promote the 
ability of the productive system to respond to the social demand for well-being using a quantity of environmental resources drastically lower than the levels currently practiced. This requires coordinated management of all available instruments (products, services and communications) and to give unity and clarity to the new proposals (MANZINI \& VEZZOLI, 2002, p.23)

In the contemporary city, the systems of standardization of this kind of participatory interventions are still in the process of being developed and perfected in order to seek the empowerment and solution of urgent problems of the communities. As an example we can cite the recent processes developed in Bologna, Milan and Apulia in Italy (SELLONI \& MANZINI, 2016; BOLOGNA, 2014). Interventions of different types cannot be dismissed because of their smaller scale, since the interest rather than a product is the construction of a network of individuals capable of mobilizing actively to work as a team with a mission, to improve their quality of life and that of their fellows.

\section{Conclusions}

It is very interesting for the designers the possibilities of intervention offered by a new vision of Design focused on sustainability and social re-assembly. There are many possible solutions to urgent problems in the city that are not currently served by a practice focused on priorities determined by capitalist consumerism.

The problems of the contemporary city demand of the designer of the 21 st century a reflection of their social function and their ability to rethink their discipline; beyond the development of products, consolidate itself as a dynamizer of intelligent solutions to social problems.

The social design appears recently in the panorama of the theory and practice of Design. Although his references can be traced several decades back to the thoughts of Papanek, Bonsiepe, among many others, but that from the context in crisis and the changing complexity of the contemporary world, make these thoughts more and more effective, and the historical moment In which ideas and actions unfold, the scenario conducive to its development and application, ceasing to be an utopia to become a reality of work for designers in the 21 st century.

It is necessary to rethink the products of the Design for this new practice focused on the social, increasingly is necessary the development of intangible products as a result of participatory processes that can solve urgent problems in society. Network building, local empowerment and the generation of tools for the expression of human groups must be increasingly appropriated by new designers in their language and forms of production.

\section{Acknowledgments}

We are grateful to the Administrative Department of Science, Technology and Innovation -COLCIENCIAS-, and the department of Sucre, Colombia, for the support of the scholarship obtained in the call for training of high level human capital for the department of Sucre, 2014.

\section{References}

ABDEL-HADI, A. (2012) Culture, Quality of life, Globalization and beyond. Procedia - Social and Behavioral Sciences 50: 11 - 19, 2012.

BERCU, A. M. The Sustainable Local Development in Romania-Key Issues for Heritage Sector. ProcediaSocial and Behavioral Sciences, 188: 144-150, 2015.

BOLOGNA. Bologna Regulation on Public Collaboration for Urban Commons. Fondazione del Monte di Bologna e Ravenna. LabGov - LABoratory for the GOVernance of commons, 2014. (http://www.labgov.it) Available in: http://www.labgov.it/wpcontent/uploads/sites/9/Bologna-Regulation-oncollaboration-between-citizens-and-the-city-for-the-cureand-regeneration-of-urban-commons1.pdf access February 07, 2017.

BONSIEPE, G. Teoría práctica del diseño industrial. Elementos para una manualística crítica. Barcelona, Gustavo Gili S.A., 1978.

BONSIEPE, G. Design, cultura e sociedade. São Paulo, Blucher. 2011. $270 \mathrm{p}$.

BONSIEPE, G. 40 anos depois. Entrevista com Gui Bonsiepe, Por Gabriel Patrocinio e José Mauro Nunes. Cap. In: Patrocinio, G., Nunes, J. M. (Org.) Design \& desenvolvimento: 40 anos depois. São Paulo: Blucher, 2015a. 264 p.

BONSIEPE, G. Do material ao digital. São Paulo, Blucher, 2015b.

BROWER C.; MALLORY R. \& Z. OHLMAN, Diseño Eco-experimental, Barcelona, España. Ed. Gustavo Gili, 2007.

BULDUK, B. An analysis of the use of urban furniture in city advertising in terms of aesthetic/visual appreciation training: city design. Procedia-Social and Behavioral Sciences, 46: 3279-3283, 2012.

CARDOSO, R. Design para um mundo complexo. São Paulo, Brasil. Ed. Cosac Naify, 2012.

CASTELLS, M. (2012) La cuestión urbana. 15a edición. México, DF. Siglo XXI editores, 2012.

CHEN, D. -S., CHENG, L. -L., HUMMELS, C., \& KOSKINEN, I. Social design: An introduction. International Journal of Design, 10(1): 1-5, 2016.

EKOMADYO, A., \& YULIAR, S. Social Reassembling as Design Strategies. Procedia-Social and Behavioral Sciences, 184: 152-160, 2015.

EL-HUSSEINY, M. A., \& KESSEIBA, K. Challenges of social sustainability in neo-liberal Cairo: re-questioning the role of public space. Procedia-Social and Behavioral Sciences, 68: 790-803, 2012.

ELRAHMAN, A. S. A. Tactical Urbanism "A Pop-up Local Change for Cairo's Built Environment". ProcediaSocial and Behavioral Sciences, 216: 224-235, 2016. 
GIRAUT, F. Bioregionalization and territorial complexity in the global South. Procedia Social and Behavioral Sciences 14: 49-52, 2011.

HARUN, N. Z., ZAKARIYA, K., MANSOR, M., \& ZAKARIA, K. Determining attributes of urban plaza for social sustainability. Procedia-Social and Behavioral Sciences, 153: 606-615, 2014.

IBARRA, D. Desarrollo mundial evanescente. Journal of Economic Literature (JEL): vol. 11 núm. 32: 3-20, 2014.

KUMAR, V., RAHMAN, Z., KAZMI, A. A., \& GOYAL, P. Evolution of sustainability as marketing strategy: Beginning of new era. Procedia-Social and Behavioral Sciences, 37: 482-489, 2012.

LATOUR, B. Reassembling the social: an introduction to actor-network theory. New York: Oxford University Press, 2005. Available in:

$<$ https://books.google.es/books?hl=es\&lr=\&id=AbQSD AAAQBAJ\&oi=fnd\&pg=PR7\&dq=Latour, + B. $+(2005)$. + Reassembling+the+social:+an+introduction+to+actornetwork+theory. + New + York:+OxfordUniversity+Press. \&ots $=9 \mathrm{~h} 7 \mathrm{Tzo} 1 \mathrm{dsT} \& \mathrm{sig}=\mathrm{pKIwJ} 06$ APSZQWZiC1NX6zc $8 \mathrm{SOr} 8 \# \mathrm{v}=$ onepage $\& \mathrm{q}=$ Latour $\% 2 \mathrm{C} \% 20 \mathrm{~B} . \% 20(2005) . \% 2$ 0Reassembling\%20the $\% 20$ social $\% 3 \mathrm{~A} \% 20 \mathrm{an} \% 20$ introdu ction $\% 20$ to $\% 20$ actor-

network\%20theory.\%20New\%20York\%3A\%20Oxford University\%20Press.\&f=false $>$ access January 10, 2017.

LAWSON, B. R. How designers think. London: the Architectural Press. 1980.

LYDON, M., BARTMAN, D., WOUDSTRA, R. \& KHAWAZARD, A. Tactical urbanism 1. Short-term action, long-term change. Street Plans Collective. 2012. Available in: $<$ https://issuu.com/streetplanscollaborative/docs/tactical urbanism_vol.1> Access January 10, 2017.

MCKENZ̄IE, S. Social Sustainability: Towards Some Definitions. Working Paper Series No 27. Hawke Research Institute. University of South Australia, Magill, South Australia. 2004. (disponible en:

$<$ http://w3.unisa.edu.au/hawkeinstitute/publications/dow nloads/wp27.pdf $>$ access January 10, 2017.

MANZINI, E. Design in a changing, connected world. Strategic Design Research Journal, Vol. 7(2): 95-99 May-August 2014, doi: 10.4013/sdrj.2014.72.06

MANZINI, E., \& RIZZO, F. Small projects/large changes: Participatory design as an open participated process. CoDesign, 7(3-4): 199-215, 2011.

MANZINI, E., VEZZOLI, C. O desenvolvimento de produtos sustentáveis. Os requisitos ambientais dos produtos industriais. São Paulo, Brasil. Editora da Universidade de São Paulo. 2002. 368 p.

MATEI, C. Globalization - An Anthropological Approach. Procedia - Social and Behavioral Sciences 149: 542 - 546, 2014.

MOURA, M. (Org.) Design brasileiro contemporâneo: reflexões. São Paulo, Ed. Estação das letras e cores, 2014, 136 p.

MULGAN, G., TUCKER, S., ALI, R., SANDERS, B. Social Innovation. What is it, why it matters and how it can be accelerated. The Basingstoke Press, The Young Foundation, 2007, available in: http://youngfoundation.org/wp-
content/uploads/2012/10/Social-Innovation-what-it-iswhy-it-matters-how-it-can-be-accelerated-March2007.pdf / access February 7, 2017.

PAPANEK, V. Arquitectura e Design - Ecologia e ética. Edições 70 Ltda. Lisboa. 2007. 288 p.

PATARAKIN, Y., \& SHILOVA, O. Concept of Learning Design for Collaborative Network Activity. Procedia-Social and Behavioral Sciences, 214, 10831090, 2015.

SALONIA, P. Tourism, migration, heritage, culture, inclusion: recovering the memory of ourselves for the sustainable cities and the society of the XXI century. Procedia - Social and Behavioral Sciences 223: 668 675, 2016.

SANDERS, E. B. N., \& STAPPERS, P. J. Co-creation and the new landscapes of design. Co-design, 4(1): 5-18, 2008. DOI: $10.1080 / 15710880701875068$

SELLONI, D., \& MANZINI, E. (2016). Policy constellations as ecosystems of design actions: Exploring three cases of social innovation policies in Italy. Strategic Design Research Journal, 9(2): 128- 136, 2016. 